\title{
Expression of stem cell factor in gastrointestinal stromal tumors: Implications for proliferation and imatinib resistance
}

\author{
XIAO-WEI HOU ${ }^{1,2}$, CHEN-GUANG BAI ${ }^{1}$, XIAO-HONG LIU ${ }^{3}$, CEN QIU ${ }^{1}$, \\ LING HUANG $^{1}$, JING-JING XU ${ }^{1}$ and DA-LIE MA ${ }^{1}$ \\ ${ }^{1}$ Department of Pathology, Changhai Hospital, Second Military Medical University, Shanghai 200433; \\ ${ }^{2}$ Department of Oncology, 401 Hospital of PLA, Qingdao, Shandong 266071; ${ }^{3}$ Institute of Cardiothoracic Surgery, \\ Changhai Hospital, Second Military Medical University, Shanghai 200433, P.R. China
}

Received August 29, 2012; Accepted October 31, 2012

DOI:10.3892/ol.2012.1019

\begin{abstract}
KIT autophosphorylation caused by mutation of $K I T$ is considered to be a critical mechanism for the oncogenesis of gastrointestinal stromal tumors (GISTs). However, little is known regarding whether stem cell factor (SCF), the KIT ligand, is able to induce the proliferation of GIST cells by activating the wild-type KIT receptor in GISTs. Imatinib, a tyrosine kinase inhibitor, has been demonstrated to be effective as treatment for the majority of GISTs. However, primary resistance to imatinib in GISTs with wild-type KIT and acquired resistance in GISTs with mutant KIT are becoming increasingly significant problems. The aims of this study were to detect the expression and function of SCF in 68 GIST samples, and to explore the relationship between SCF activity and imatinib resistance using immunohistochemical staining and western blot analysis. Results showed abundant expression of SCF in GISTs and demonstrated that SCF is capable of enhancing GIST cell proliferation. Similar to its ineffectiveness in wild-type GISTs, imatinib also failed to inhibit SCF-induced KIT activation in GISTs with mutant KIT. We also found increased SCF expression in GIST cells treated with imatinib. Overall, our results indicated that SCF-induced KIT activation is a novel essential pathway for the proliferation of GISTs. Imatinib was not able to inhibit the activity of SCF, while it promoted the expression of SCF, which may have contributed to acquired imatinib resistance.
\end{abstract}

\section{Introduction}

KIT is a transmembrane glycoprotein that belongs to the type III tyrosine kinase receptor family (1). Upon binding its ligand, stem cell factor (SCF), the KIT receptor dimerizes and

Correspondence to: Professor Da-Lie Ma, Department of Pathology, Changhai Hospital, Second Military Medical University, 168 Changhai Road, Shanghai 200433, P.R. China

E-mail: madalie9@gmail.com

Key words: stem cell factor, gastrointestinal stromal tumor, KIT, imatinib resistance initiates a signal transduction phosphorylation cascade that results in the regulation of cell growth. SCF is encoded by the Steel gene and is present in both membrane-bound (mSCF) and soluble (sSCF) forms (2). KIT that has been activated by $\mathrm{mSCF}$ is considered to be stable and maintains its activity (3). The SCF/KIT system plays a key role in the differentiation and proliferation of the interstitial cells of Cajal (ICCs) and hematopoietic cells (4). The SCF/KIT system is also involved in cell proliferation in certain tumors, including mast cell leukemia, seminoma and malignant melanoma, as well as lung, small cell, breast, gastric, colon, cervical and ovarian cancer (5-10).

Gastrointestinal stromal tumors (GISTs) are the most common mesenchymal neoplasm of the gastrointestinal tract and they originate from the ICCs or their precursor cells (11). GISTs are defined as tumors that are typically immunoreactive for KIT. Unlike the SCF/KIT tumors mentioned previously, $\sim 75-80 \%$ of GISTs have a gain-of-function mutation in the KIT proto-oncogene encoding the KIT protein (12-15). These mutations lead to constitutive oncogenic signaling in the absence of SCF. Uncontrolled KIT activity results in the oncogenesis and proliferation of GISTs. However, it has been demonstrated that $94 \%$ of GIST mutations are heterozygous, i.e., wild-type KIT remains present in the majority of GISTs (16). It is not yet known whether these wild-type KIT are capable of being activated by their ligand, SCF, and are involved in the proliferation of GISTs.

Imatinib, a small molecule tyrosine kinase inhibitor, has been demonstrated to be effective in the treatment of recurrent or metastatic GISTs by inhibition of KIT activation. Findings of a previous study confirmed that KIT activation is a ubiquitous feature of GISTs, even in the absence of KIT mutations (14). However, based on certain clinical trials, the best response rates to imatinib have been observed in GISTs with KIT mutations (12,17-18). GISTs with wild-type KIT have demonstrated primary resistance to imatinib, and a considerable proportion of GISTs with mutant KIT have demonstrated acquired resistance at a later stage (19). These clinical trials revealed that imatinib was not capable of effectively inhibiting wild-type KIT activation in GISTs lacking a KIT mutation. If SCF is able to function as the ligand that activates wild-type KIT in heterozygous GISTs, we hypothesize that imatinib is also likely to fail to inhibit wild-type KIT activation. 
Table I. Details of GIST primary cultures.

\begin{tabular}{|c|c|c|c|c|}
\hline GIST case no. & Age (years) & Origin & Tumor size $(\mathrm{cm})$ & KIT mutation \\
\hline 0917833 & 53 & Stomach & 6.0 & Exon 11 DEL557-558 \\
\hline 0919049 & 41 & Stomach & 3.0 & Exon 11 DEL555-558 \\
\hline 0919298 & 68 & Stomach & 2.6 & Exon 11 DEL557-558 \\
\hline 0930644 & 37 & Small intestine & 2.0 & Exon 9 INS502-503 \\
\hline 0930830 & 58 & Small intestine & 8.0 & Exon 9 INS502-503 \\
\hline 1002977 & 56 & Small intestine & 11.0 & Exon 9 INS502-503 \\
\hline 1002979 & 59 & Stomach & 7.5 & Exon 11 DEL576 \\
\hline
\end{tabular}

All patients were male. GIST, gastrointestinal stromal tumor; DEL, deletion; INS, insertion.

In the present study, we examined the expression of SCF in GISTs, analyzed the relationship between SCF expression and the proliferative activity of GIST cells, and studied the role of SCF in the proliferation of GIST cells. We verified our theory by examining KIT activation in SCF-stimulated GIST cells pretreated with imatinib. We also observed the level of SCF expression in GIST cells following treatment with imatinib.

\section{Materials and methods}

Patient samples. Clinical samples were obtained with informed consent. A total of 68 GIST samples were included in the study. All cases were confirmed as GIST by at least two pathologists. The tumor size, number of mitotic cells in 50 high-power fields (HPF) and Ki-67 index were observed by hematoxylin and eosin (HE) staining or immunohistochemistry. For the histological and immunohistochemical analyses, tissue specimens were fixed in $10 \%$ formalin and embedded in paraffin. Core tissue biopsies ( $2 \mathrm{~mm}$ in diameter) were taken from individual paraffin-embedded tumor tissues and arranged in new recipient paraffin blocks using a Tissue Microarrayer (Beecher Instruments, Silver Spring, MD, USA). For each tumor, the representative tumor areas were selected using HE staining. For western blot analysis and mutation detection, 21 fresh tissue specimens were frozen and stored at $-80^{\circ} \mathrm{C}$.

Immunohistochemical detection. Immunohistochemical staining was performed using anti-SCF antibody (rabbit monoclonal; 1:50 dilution; Abcam, Cambridge, MA, USA), anti-KIT antibody (rabbit polyclonal; 1:500 dilution; DakoCytomation, Glostrup, Denmark) and anti-Ki-67 antibody (mouse monoclonal; MIB-1; 1:200 dilution; DakoCytomation). The TMA sections $(4 \mu \mathrm{m})$ were deparaffinized and boiled in $10 \%$ citric acid buffer solution ( $\mathrm{pH} \mathrm{6.0)}$ ) for 20 min for antigen retrieval. Following blocking of endogenous peroxidase activity with $3 \%$ hydrogen peroxide, specimens were incubated with primary antibodies at $4^{\circ} \mathrm{C}$ overnight. Bound antibodies were detected by a peroxidase-labeled, polymer-conjugated secondary antibody (EnVision HRP; DakoCytomation), and subjected to peroxidase staining using diaminobenzidine (DAB) as a substrate. Slides were counterstained with hematoxylin. The $\mathrm{Ki}-67$ labeling index was calculated as the percentage of $\mathrm{Ki}-67$-positive cells among all tumor cells in $5 \mathrm{HPF}$.

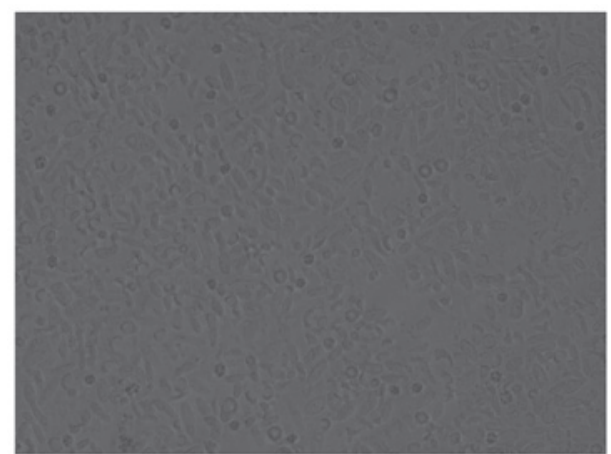

Figure 1. Primary cultures of gastrointestinal stromal tumor (GIST) cells.

Detection of KIT mutations. Genomic DNA of fresh or paraffin-embedded tissues was extracted using a standard proteinase-K digestion/phenol-chloroform procedure. KIT exons 11 and 9 were amplified using the following primer sequences and annealing temperatures: Exon 11, forward: 5'-CCAGAGTGCTCTAATGACTG-3' and reverse: 5'-AGC CCCTGTTTCATACTGAC-3' at $60^{\circ} \mathrm{C}$; exon 9, forward: 5'-GCCACATCCCAAGTGTTTTATG-3' and reverse: 5'-GAG CCTAAACATCCCCTTAAATTG- $3^{\prime}$ at $56^{\circ} \mathrm{C}$. Sequencing analysis was performed directly on the PCR products.

Cell isolation and primary cell culture. Fresh GIST tissues were minced with scissors, washed twice with phosphate-buffered saline (PBS), and then ground into single-cell suspensions by filtering through the sieve with $200 \mu \mathrm{m}$ mesh. After washing in cold PBS, cell pellets were resuspended in RPMI-1640 medium supplemented with $10 \%$ fetal calf serum (FCS; Gibco, France) and seeded onto culture dishes (Fig. 1). Cells were cultured overnight prior to analysis. Simultaneously, all the cells that had been isolated from GIST tissue were analyzed for KIT mutations (Table I).

In vitro cell proliferation assay and drug testing. GIST cells were FCS-starved for $4 \mathrm{~h}$ and then cultured in the appropriate culture medium with $100 \mathrm{ng} / \mathrm{ml}$ recombinant human SCF (rhSCF, Peprotech, Inc., Rocky Hill, NJ, USA) for $72 \mathrm{~h}$. Viable cells were measured with the Cell Counting kit 8 (Wako, Osaka, Japan) according to the manufacturer's instructions. GIST cells were FCS-starved for $4 \mathrm{~h}$, stimulated by rhSCF 
Table II. Number of mitotic cells and Ki-67 index in SCF-positive cases compared with SCF-negative cases.

\begin{tabular}{lcrr}
\hline & No. of SCF-positive cases & No. of SCF-negative cases & P-value \\
\hline No. of mitotic cells (per 50 HPF) & 36 & 15 & 0.049 \\
$\leq 10$ & 16 & 1 & 0.001 \\
$>10$ & & & \\
Ki-67 index (\%) & 15 & 12 & \\
$<5$ & 23 & 0 & \\
$5-10$ & 14 & 0 & \\
$>10$ & & & \\
\hline
\end{tabular}

for $0,5,15,30,60$ or $120 \mathrm{~min}$, and then harvested for KIT phosphorylation detection by western blot analysis. SCF expression levels were detected in GIST cells treated with or without imatinib (Novartis Pharma, Basel, Switzerland) for $72 \mathrm{~h}$ by western blot analysis. KIT phosphorylation levels were observed in GIST cells treated with imatinib for $90 \mathrm{~min}$, prior to stimulation with $100 \mathrm{ng} / \mathrm{ml} \mathrm{rhSCF}$ for $10 \mathrm{~min}$.

Western blot analysis. Frozen GIST samples were calibrated and homogenized in lysis buffer $(20 \mathrm{mM}$ Tris, $150 \mathrm{mM} \mathrm{NaCl}$, $1 \mathrm{mM}$ othovanadate, $10 \mathrm{mM} \mathrm{NaF}, 1 \mathrm{mM}$ PMSF, $0.5 \mu \mathrm{g} / \mathrm{ml}$ leupeptin, $1 \mu \mathrm{g} / \mathrm{ml}$ pepstatin, $10 \mathrm{KIU} / \mathrm{ml}$ aprotinin and $1 \%$ triton X-100). Lysates were rocked at $4^{\circ} \mathrm{C}$ for $30 \mathrm{~min}$ and then centrifuged at 12,000 rpm for $15 \mathrm{~min}$. Supernatant protein concentrations were measured using a BAC Protein Assay kit (Merck KGaA; Darmstadt, Germany), and $50 \mu$ g of protein were separated by 8 or $12 \%$ SDS-polyacrylamide gel electrophoresis and transferred to a polyvinylidene difluoride membrane. The membrane was blocked for $60 \mathrm{~min}$ at room temperature with $5 \%$ skimmed milk or bovine serum albumin (BSA) and then reacted with anti-KIT antibody (DakoCytomation), anti-SCF antibody (Abcam), or anti-c-kit (phospho Y703) (Abcam), as the primary antibody. Peroxidase-labeled anti-rabbit $\operatorname{IgG}$ was used as the secondary antibody. The Western Lightning chemiluminescence reagent (Santa Cruz Biotechnology, Inc.; Santa Cruz, CA, USA) was used for the detection of proteins.

\section{Results}

SCF expression in GISTs and its correlation with tumor proliferation. The expression of KIT and its ligand SCF were detected by immunohistochemical staining in 68 GIST samples. All GIST samples demonstrated KIT positivity. Expression of SCF was observed in 52 cases (Fig. 2A). The SCF-positive cases presented moderate or strong staining in the membrane and cytoplasm of GIST cells. Expression of SCF was further demonstrated by western blot analysis in fresh GIST tissues that stained positive for SCF by immunohistochemistry. As shown in Fig. 2B, a positive signal was detected at $31 \mathrm{kDa}$ that corresponded to the membrane-bound form of SCF in 17 out of 21 cases. In those 17 tumors, the signal for KIT, which has a molecular weight of $145 \mathrm{kDa}$, was also confirmed in the tumor tissues (Fig. 2B).

We then examined the association between SCF expression and the proliferative activity of tumors. The Ki-67 index and the number of mitotic cells in $50 \mathrm{HPF}$ were used to evaluate

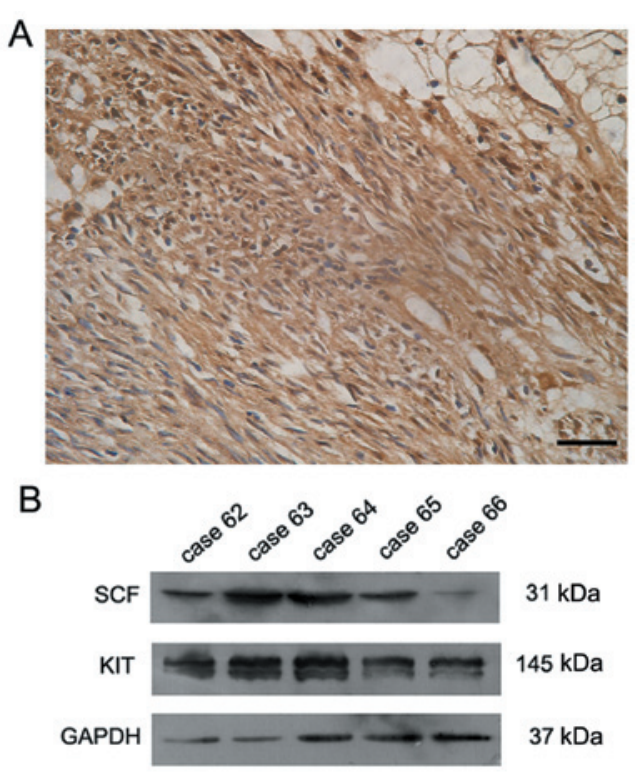

Figure 2. Expression of SCF and KIT in gastrointestinal stromal tumors (GISTs) by immunohistochemistry and western blot analysis. (A) Expression of stem cell factor (SCF) protein in GISTs revealed by immunohistochemistry. SCF staining areas are on the membrane and in the cytoplasm of cells. (B) Western blot analysis of SCF and KIT protein. The bands at 31 and $145 \mathrm{kDa}$ correspond to SCF and KIT protein, respectively.

the proliferation potential of the GIST cells. The expression rate of $\mathrm{Ki}-67$ and the number of mitotic cells in SCF-positive cases were significantly higher than those of SCF-negative cases $(\mathrm{P}<0.001$ and $\mathrm{P}<0.05$, respectively; Mann-Whitney $\mathrm{U}$ test; Table II).

Correlation between c-kit mutations and SCF expression. A total of 54 GIST samples were investigated for mutations in the KIT proto-oncogene (exons 9 and 11). Exons 9 and 11 have been demonstrated to be frequently mutated in GISTs. DNA sequencing results obtained for all 54 samples are listed in Table III. The correlation of KIT mutations with SCF expression was analyzed by a McNemar's test. No correlation was observed between the presence of KIT mutations and the expression of SCF $(\mathrm{P}>0.05)$.

Proliferation of GIST cells stimulated by SCF. To investigate the function of SCF/KIT signaling in GIST cells, primary GIST cells were incubated for $72 \mathrm{~h}$ with SCF at concentrations of $0,1,10$ and $100 \mathrm{ng} / \mathrm{ml}$, and their viability and rate 
Table III. KIT mutation details of the 54 cases of GIST.

\begin{tabular}{|c|c|c|c|c|c|c|}
\hline Case no. & Gender & Age (years) & $\mathrm{SCF}$ & Origin & Tumor size (cm) & KIT mutation \\
\hline 1 & $\mathrm{~F}$ & 40 & - & Small intestine & 4.0 & $\mathrm{Wt}$ \\
\hline 2 & $\mathrm{M}$ & 36 & + & Stomach & 5.0 & $\mathrm{Wt}$ \\
\hline 3 & $\mathrm{M}$ & 61 & + & Stomach & 5.5 & Exon 11 V560D \\
\hline 4 & M & 43 & + & Stomach & 5.0 & Exon 11 DEL555-556 \\
\hline 8 & $\mathrm{~F}$ & 50 & + & Small intestine & 5.0 & $\mathrm{Wt}$ \\
\hline 9 & $\mathrm{~F}$ & 56 & + & Stomach & 4.5 & Exon 11 DEL556-582 \\
\hline 10 & $\mathrm{~F}$ & 72 & + & Stomach & 2.0 & $\mathrm{Wt}$ \\
\hline 13 & $\mathrm{M}$ & 59 & - & Stomach & 4.0 & $\mathrm{Wt}$ \\
\hline 15 & $\mathrm{M}$ & 34 & + & Small intestine & 3.5 & Exon 9 INS502-503 \\
\hline 16 & $\mathrm{~F}$ & 49 & + & Stomach & 4.0 & Exon 11 DEL555-558 \\
\hline 17 & $\mathrm{~F}$ & 52 & + & Unknown & 9.0 & Exon 9 INS502-503 \\
\hline 18 & $\mathrm{M}$ & 43 & + & Small intestine & 3.5 & Exon 11 DEL553-554 \\
\hline 19 & $\mathrm{~F}$ & 78 & - & Stomach & 5.0 & Exon 11 DEL555-558 \\
\hline 20 & $\mathrm{~F}$ & 61 & + & Small intestine & 5.0 & Exon 11 DEL555-559 \\
\hline 21 & $\mathrm{~F}$ & 59 & + & Stomach & 3.0 & $\mathrm{Wt}$ \\
\hline 22 & M & 49 & + & Small intestine & 2.5 & $\mathrm{Wt}$ \\
\hline 23 & $\mathrm{~F}$ & 53 & + & Stomach & 2.5 & $\mathrm{Wt}$ \\
\hline 27 & $\mathrm{M}$ & 63 & - & Stomach & 5.0 & Exon 11 V559D \\
\hline 28 & M & 48 & + & Stomach & 3.0 & Exon 11 DEL565-572 \\
\hline 29 & $\mathrm{~F}$ & 39 & + & Stomach & 18.0 & Exon 11 INS577-579 \\
\hline 30 & $\mathrm{~F}$ & 48 & + & Small intestine & 12.0 & $\mathrm{Wt}$ \\
\hline 31 & M & 71 & + & Stomach & 5.5 & $\mathrm{Wt}$ \\
\hline 32 & M & 53 & + & Rectum & 6.0 & Exon 11 W557R \\
\hline 33 & M & 45 & + & Small intestine & 2.0 & $\mathrm{Wt}$ \\
\hline 34 & $\mathrm{~F}$ & 73 & + & Stomach & 6.0 & Exon 11 V559D \\
\hline 37 & $\mathrm{~F}$ & 57 & + & Stomach & 6.5 & $\mathrm{Wt}$ \\
\hline 38 & $\mathrm{M}$ & 54 & - & Small intestine & 6.0 & Exon 11 DEL579 \\
\hline 40 & M & 68 & - & Small intestine & 7.0 & Exon 11 DEL557-558 \\
\hline 41 & $\mathrm{~F}$ & 48 & + & Stomach & 3.0 & Exon 11 DEL557-558 \\
\hline 42 & $\mathrm{~F}$ & 73 & - & Stomach & 2.5 & Exon 11 DEL555-557 \\
\hline 43 & $\mathrm{M}$ & 50 & + & Stomach & 4.0 & $\mathrm{Wt}$ \\
\hline 45 & $\mathrm{~F}$ & 37 & + & Small intestine & 3.0 & Exon 11 INS557-582 \\
\hline 47 & $\mathrm{~F}$ & 51 & + & Small intestine & 2.5 & Exon 9 INS502-503 \\
\hline 48 & $\mathrm{~F}$ & 49 & + & Stomach & 5.0 & Exon 11 INS577-582 \\
\hline 49 & $\mathrm{M}$ & 78 & + & Stomach & 14.0 & Exon 11 DEL555-558 \\
\hline 50 & $\mathrm{~F}$ & 41 & + & Unknown & 8.0 & Exon 11 V560D \\
\hline 53 & M & 77 & + & Stomach & 5.5 & Exon 11 V559D \\
\hline 54 & $\mathrm{~F}$ & 55 & + & Stomach & 22.0 & Exon 11 DEL555-559 \\
\hline 55 & $\mathrm{~F}$ & 82 & + & Small intestine & 3.5 & Exon 11 DEL553-554 \\
\hline 56 & $\mathrm{~F}$ & 55 & + & Small intestine & 5.0 & Exon 9 INS502-503 \\
\hline 57 & $\mathrm{~F}$ & 84 & - & Stomach & 5.0 & $\mathrm{Wt}$ \\
\hline 58 & $\mathrm{~F}$ & 55 & + & Stomach & 4.0 & Exon 11 DEL555-558 \\
\hline 59 & M & 60 & + & Stomach & 2.8 & Exon 11 DEL565-572 \\
\hline 60 & $\mathrm{~F}$ & 75 & + & Stomach & 6.0 & Exon 11 INS577-579 \\
\hline 61 & $\mathrm{~F}$ & 63 & + & Small intestine & 3.0 & Exon 9 INS502-503 \\
\hline 62 & M & 47 & + & Stomach & 3.0 & Exon 11 DEL576 \\
\hline 63 & $\mathrm{M}$ & 35 & + & Stomach & 6.5 & Exon 11 INS575-582 \\
\hline 64 & M & 60 & + & Small intestine & 3.2 & Exon $9 \mathrm{~S} 451 \mathrm{C}$ \\
\hline 65 & $\mathrm{~F}$ & 59 & + & Stomach & 14.0 & Exon 11 DEL557-558 \\
\hline 66 & M & 75 & - & Stomach & 15.0 & Exon 11 DEL550-558 \\
\hline 67 & $\mathrm{M}$ & 53 & + & Stomach & 6.0 & Exon 11 DEL579 \\
\hline 68 & $\mathrm{M}$ & 29 & - & Rectum & 5.0 & $\mathrm{Wt}$ \\
\hline
\end{tabular}

GIST, gastrointestinal stromal tumor; SCF, stem cell factor; DEL, deletion; INS, insertion; Wt, wild-type. 
A

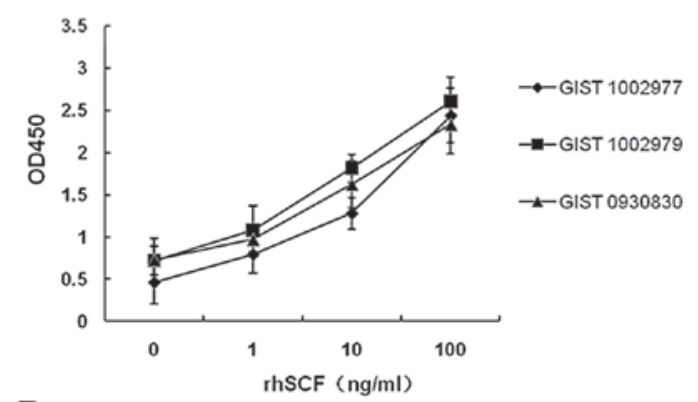

B

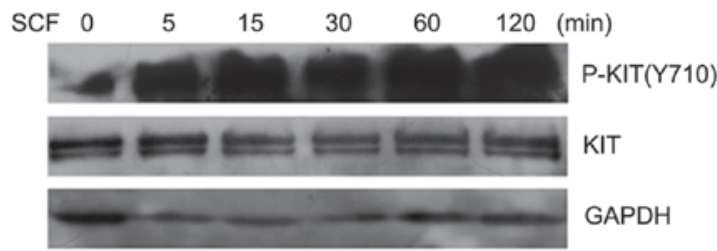

Figure 3. Gastrointestinal stromal tumor (GIST) cell responses to recombinant human stem cell factor (rhSCF). (A) Three representative samples of primary GIST cells proliferated in response to SCF in a dose-dependent manner. (B) The level of KIT phosphorylation in SCF-stimulated cells was higher than that of unstimulated cells.

A

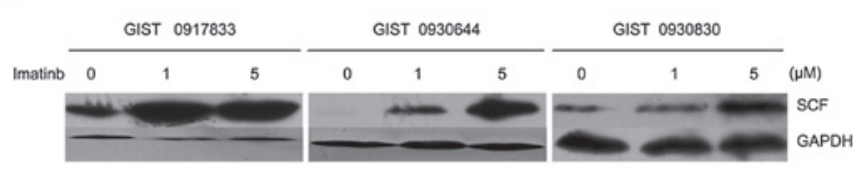

B

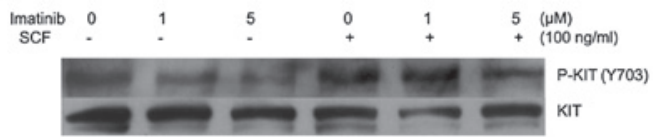

Figure 4. Effect of imatinib treatment on stem cell factor (SCF) expression and SCF-stimulated KIT activation in GIST cells. GIST cells were treated with or without imatinib and SCF. (A) SCF expression increased in three GIST samples treated with imatinib. (B) Imatinib failed to suppress the SCF-mediated activation of KIT.

of multiplication were determined by a cell count assay. The primary GIST cells from all three patients examined proliferated in response to SCF in a dose-dependent manner (Fig. 3A). We subsequently examined KIT activation in GIST cells following cultivation with or without SCF. The levels of KIT phosphorylation in SCF-stimulated cells were higher than those of unstimulated cells (Fig. 3B). These results suggest that $\mathrm{SCF}$, as the ligand of KIT, is capable of activating its receptor in GIST cells. In addition, the results suggest that the SCF/KIT signaling pathway plays a key role in the proliferation of GIST cells.

Effect of imatinib treatment on SCF expression and SCF-stimulated KIT activation in GIST cells. Treatment with imatinib has been shown to result in an increased SCF concentration in the serum of GIST patients (20). To test the effect of imatinib treatment on SCF expression of primary GIST cells in vitro, FCS-starved GIST cells were treated with imatinib for $72 \mathrm{~h}$ and then analyzed by western blot analysis for SCF expression. The SCF signal was stronger in imatinib-treated compared with untreated GIST cells (Fig. 4A). These results suggest that imatinib is capable of increasing endogenously produced SCF in cultured GIST cells. We then examined the inhibitory effects of imatinib on KIT activation that has been induced by stimulation with exogenous SCF. GIST cells were pre-treated with or without imatinib and then stimulated with $100 \mathrm{ng} / \mathrm{ml}$ SCF. Following the $100 \mathrm{ng} / \mathrm{ml} \mathrm{SCF}$ stimulation, higher levels of KIT phosphorylation remained present in GIST cells. An increased dose of $5 \mu \mathrm{M}$ imatinib was not able to inhibit KIT phosphorylation in SCF-stimulated cells in vitro (Fig. 4B). These results suggest that imatinib may not effectively inhibit KIT phosphorylation that has been induced by its ligand (SCF).

\section{Discussion}

In this study, we observed abundant SCF expression in GIST tissues, which suggested an autocrine mechanism of SCF. Western blot analysis verified that the SCF protein expressed in GISTs is predominantly present as the membrane-bound form, which has the ability to stably and continuously activate its receptor, KIT. Our data also demonstrated co-expression of SCF and KIT in GISTs, and SCF expression was significantly correlated with an increased proliferative potential of GISTs. A previous study (21) also SCF expression in GISTs, as well as a larger tumor size and higher MIB-1 index in SCF-positive cases. The present data, together with these findings, suggest that SCF may be a potential marker for GIST proliferation.

There are two mechanisms of activation of KIT in malignant tumors. One is autophosphorylation of KIT due to gain-of-function mutations of the c-kit gene, and the other is ligand-dependent activation. The present study did not detect a correlation between SCF expression and the status of KIT mutation in GISTs. These data suggest that SCF-induced KIT activation is an independent mechanism in GISTs, regardless of KIT autophosphorylation. A previous study (22) demonstrated that the fraction of activated KIT was not correlated with the fraction of mutant KIT in GISTs. The absence of a correlation may be explained by ligand-dependent SCF/KIT signaling in GISTs.

SCF stimulation of GIST544 cells, which express a heterozygous c-kit exon 9 mutation, induces stronger KIT phosphorylation (23). SCF treatment of GIST882 cells, which contain a homozygous c-kit exon 13 mutation, does not induce high levels of KIT phosphorylation (24). One isoform of KIT that contains a 4 amino acid sequence, GNNK, has been demonstrated to be the most abundant isoform in GISTs (25). Following stimulation with SCF, wild-type GNNK-negative KIT induced an improvement in cell survival and stronger proliferation (26). In the present study, we also demonstrated that SCF was capable of inducing GIST cell proliferation in vitro. Additionally, a high level of KIT phosphorylation in SCF-stimulated cells was observed. All GIST cells were verified to contain heterozygous, functional mutations of c-kit. Thus, this study has demonstrated that SCF may activate wild-type KIT in GISTs and participate in the activation of heterozygous KIT mutants. 
Notably, the results of the present study demonstrated increased SCF expression levels in imatinib-treated GIST cells. Tumor growth is complicated and multiple signaling pathways are involved in the survival and proliferation of tumor cells. Therefore, it is possible that in GISTs, after activation of the mutant KIT is inhibited by imatinib, other compensatory signals may become involved in maintaining tumor cell survival. As a result, increased SCF expression levels may be a response that facilitates preservation of the wild-type KIT signaling in GISTs. A previous study (27) demonstrated that mutant KIT was mainly retained within the endoplasmic reticulum and Golgi compartments in an immature constitutively phosphorylated form, whereas wild-type KIT was expressed at the plasma membrane in a mature non-phosphorylated form. Imatinib-induced inhibition of the phosphorylation of mutant KIT proteins resulted in the restoration of KIT expression at the cell surface. Our data, together with those findings, suggest that increased expression of SCF and KIT at the cell surface due to imatinib treatment results in abundant SCF/KIT signaling activation. Although the inhibitor imatinib blocked the ligandindependent signaling of KIT, it simultaneously enhanced the ligand-dependent signaling. Negri et al (28) also demonstrated that the surgical samples of imatinib-treated GISTs were characterized by high expression levels and activation of the wild-type KIT receptor, together with high expression levels of its ligand. These findings provide a favorable compliment to our study in vivo.

In this study, we verified the inefficiency of imatinib for the inhibition of KIT phosphorylation stimulated by SCF in vitro. In clinical studies, it has been confirmed that GISTs with no KIT mutations demonstrate resistance to imatinib. A clinical study (29) also found that there was no clinical efficacy of imatinib in uveal melanomas expressing SCF/KIT without mutations. These results suggest that the ligand-dependent activation of KIT is likely to have primary resistance to imatinib, while the stronger ligand-independent activation of wild-type KIT due to imatinib treatment may contribute to the development of acquired resistance.

In conclusion, the expression of SCF suggests an autocrine mechanism in GISTs. It is likely that ligand-independent KIT activation due to gain-of-function mutations in the KIT gene is the main mechanism of GIST oncogenesis, whereas the ligand-dependent activating mechanism is the crucial reason for tumor proliferation. The activation of SCF/KIT signaling may be a considerable contributing factor in imatinib resistance. Our study suggests that the simultaneous inhibition of ligand-dependent and ligand-independent activation of KIT may be a more effective strategy for GIST therapy.

\section{Acknowledgements}

This study was supported by grants from the National Natural Science Foundation of China (Grant No.s 30700809 and 30972876), awarded to Professor Da-Lie Ma.

\section{References}

1. Rousset D, Agnès F, Lachaume P, André C and Galibert F: Molecular evolution of the genes encoding receptor tyrosine kinase with immunoglobulin like domains. J Mol Evol 41: 421-429, 1995.
2. Anderson DM, Lyman SD, Baird A, Wignall JM, Eisenman J, Rauch C, March CJ, Boswell HS, Gimpel SD and Cosman D: Molecular cloning of mast cell growth factor, a hematopoietin that is active in both membrane bound and soluble forms. Cell 63: 235-243, 1990.

3. Miyazawa K, Williams DA, Gotoh A, Nishimaki J, Broxmeyer HE and Toyama K: Membrane-bound steel factor induces more persistent tyrosine kinase activation and longer life span of c-kit gene-encoded protein than its soluble form. Blood 85: 641-649, 1995.

4. Cohen PS, Chan JP, Lipkunskaya M, Biedler JL and Seeger RC: Expression of stem cell factor and c-kit in human neuroblastoma. The children's cancer group. Blood 84: 3465-3472, 1994.

5. Hassan S, Kinoshita Y, Kawanami C, Kishi K, Matsushima Y, Ohashi A, Funasaka Y, Okada A, Maekawa T, He-Yao W and Chiba T: Expression of proto-oncogene c-kit and its ligand stem cell factor (SCF) in gastric carcinoma cell lines. Dig Dis Sci 43: 8-14, 1998.

6. Hines SJ, Organ C, Kornstein MJ and Krystal GW: Coexpression of the c-kit and stem cell factor genes in breast carcinomas. Cell Growth Differ 6: 769-779, 1995.

7. Inoue M, Kyo S, Fujita M, Enomoto $\mathrm{T}$ and Kondoh G: Coexpression of the c-kit receptor and the stem cell factor in gynecological tumors. Cancer Res 54: 3049-3053, 1994.

8. Krystal GW, Hines SJ and Organ CP: Organ.Autocrine growth of small cell lung cancer mediated by coexpression of c-kit and stem cell factor: Cancer Res 56: 370-376, 1996.

9. Pietsch T, Kyas U, Steffens U, Yakisan E, Hadam MR, Ludwig WD, Zsebo K and Welte K: Effects of human stem cell factor (c-kit ligand) on proliferation of myeloid leukemia cells: Heterogeneity in response and synergy with other hematopoietic growth factors. Blood 80: 1199-206, 1992.

10. Toyota M, Hinoda Y, Takaoka A, Makiguchi Y, Takahashi T, Itoh F, Imai $\mathrm{K}$ and Yachi A: Expression of c-kit and kit ligand in human colon carcinoma cells. Tumour Biol 14: 295-302, 1993.

11. Kindblom LG, Remotti HE, Aldenborg F and Meis-Kindblom JM: Gastrointestinal pacemaker cell tumor (GIPACT): gastrointestinal stromal tumors show phenotypic characteristics of the interstitial cells of Cajal. Am J Pathol 152: 1259-1269, 1998.

12. Heinrich MC, Corless CL, Demetri GD, Blanke CD, von Mehren M, Joensuu H, McGreevey LS, Chen CJ, Van den Abbeele AD, Druker BJ, Kiese B, et al: Kinase mutations and imatinib response in patients with metastatic gastrointestinal stromal tumor. J Clin Oncol 21: 4342-4349, 2003.

13. Hirota S, Isozaki K, Moriyama Y, Hashimoto K, Nishida T, Ishiguro S, Kawano K, Hanada M, Kurata A, Takeda M, Muhammad Tunio G, et al: Gain-of-function mutations of c-kit in human gastrointestinal stromal tumors. Science 279: 577-580, 1998.

14. Rubin BP, Singer S, Tsao C, Duensing A, Lux ML, Ruiz R, Hibbard MK, Chen CJ, Xiao S, Tuveson DA, Demetri GD, et al: KIT activation is a ubiquitous feature of gastrointestinal stromal tumors. Cancer Res 61: 8118-8121, 2001

15. Wardelmann E, Losen I, Hans V, Neidt I, Speidel N, Bierhoff E, Heinicke T, Pietsch T, Büttner R and Merkelbach-Bruse S: Deletion of Trp-557 and Lys-558 in the juxtamembrane domain of the c-kit protooncogene is associated with metastatic behavior of gastrointestinal stromal tumors. Int J Cancer 106: 887-895, 2003.

16. Emile JF, Théou N, Tabone S, Cortez A, Terrier P, Chaumette MT, Julié C, Bertheau P, Lavergne-Slove A, Donadieu J, Barrier A, et al: A clinicopathologic, phenotypic, and genotypic characteristics of gastrointestinal mesenchymal tumors. Clin Gastroenterol Hepatol 2: 597-605, 2004.

17. Debiec-Rychter M, Sciot R, Le Cesne A, Schlemmer M, Hohenberger P, van Oosterom AT, Blay JY, Leyvraz S, Stul M, Casali PG, Zalcberg J, et al; EORTC Soft Tissue and Bone Sarcoma Group; Italian Sarcoma Group; Australasian GastroIntestinal Trials Group: KIT mutations and dose selection for imatinib in patients with advanced gastrointestinal stromal tumours. Eur J Cancer 42: 1093-1103, 2006.

18. Heinrich MC, Corless CL, Blanke CD, Demetri GD, Joensuu H, Roberts PJ, Eisenberg BL, von Mehren M, Fletcher CD, Sandau K, McDougall K, et al: Molecular correlates of imatinib resistance in gastrointestinal stromal tumors. J Clin Oncol 24: 4764-4774, 2006.

19. Demetri GD, von Mehren M, Blanke CD, Van den Abbeele AD, Eisenberg B, Roberts PJ, Heinrich MC, Tuveson DA, Singer S, Janicek M, Fletcher JA, et al: Efficacy and safety of imatinib mesylate in advanced gastrointestinal stromal tumors. N Engl J Med 347: 472-480, 2002. 
20. Bono P, Krause A, von Mehren M, Heinrich MC, Blanke CD, Dimitrijevic S, Demetri GD and Joensuu H: Serum KIT and KIT ligand levels in patients with gastrointestinal stromal tumors treated with Imatinib. Blood 103: 2929-2935, 2004.

21. Hirano K, Shishido-Hara Y, Kitazawa A, Kojima K, Sumiishi A, Umino M, Kikuchi F, Sakamoto A, Fujioka Y and Kamma H: Expression of stem cell factor (SCF), a KIT ligand, in gastrointestinal stromal tumors (GISTs): a potential marker for tumor proliferation. Pathol Res Pract 204: 799-807, 2008.

22. Théou-Anton N, Tabone S, Brouty-Boyé D, Saffroy R, Ronnstrand L, Lemoine A and Emile JF: Co expression of SCF and KIT in gastrointestinal stromal tumours (GISTs) suggests an autocrine/paracrine mechanism. Br J Cancer 94: 1180-1185, 2006.

23. Duensing A, Medeiros F, McConarty B, Joseph NE, Panigrahy D, Singer S, Fletcher CD, Demetri GD and Fletcher JA: Mechanisms of oncogenic KIT signal transduction in primary gastrointestinal stromal tumors (GISTs). Oncogene 23: 3999-4006, 2004.

24. Lux ML, Rubin BP, Biase TL, Chen CJ, Maclure T, Demetri G, Xiao S, Singer S, Fletcher CD and Fletcher JA: KIT extracellular and kinase domain mutations in gastrointestinal stromal tumors. Am J Pathol 156: 791-795, 2000.

25. Théou N, Tabone S, Saffroy R, Le Cesne A, Julié C, Cortez A, Lavergne-Slove A, Debuire B, Lemoine A and Emile JF: High expression of both mutant and wild-type alleles of c-KIT in gastrointestinal stromal tumors. Biochim Biophys Acta 1688: 250-256, 2004.
26. Pedersen M, Rönnstrand L and Sun J: The c-Kit/D816V mutation eliminates the differences in signal transduction and biological responses between two isoforms of c-Kit. Cell Signal 21:413-418, 2009.

27. Tabone-Eglinger S, Subra F, El Sayadi H, Alberti L, Tabone E, Michot JP, Théou-Anton N, Lemoine A, Blay JY and Emile JF: KIT mutations induce intracellular retention and activation of an immature form of the KIT protein in gastrointestinal stromal tumors. Clin Cancer Res 14: 2285-2294, 2008.

28. Negri T, Bozzi F, Conca E, Brich S, Gronchi A, Bertulli R, Fumagalli E, Pierotti MA, Tamborini E and Pilotti S: Oncogenic and ligand-dependent activation of KIT/PDGFRA in surgical samples of imatinib-treated gastrointestinal stromal tumours (GISTs). J Pathol 217: 103-112, 2009.

29. Hofmann UB, Kauczok-Vetter CS, Houben R and Becker JC: Overexpression of the KIT/SCF in uveal melanoma does not translate into clinical efficacy of imatinib mesylate. Clin Cancer Res 15: 324-329, 2009. 